\title{
Determination of the Physicochemical Properties of Piroxicam
}

\section{Piroksikamın Fizikokimyasal Özelliklerinin Belirlenmesi}

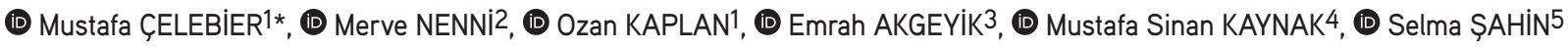 \\ 1 Hacettepe University Faculty of Pharmacy, Department of Analytical Chemistry, Ankara, Turkey \\ ${ }^{2}$ Çukurova University Faculty of Pharmacy, Department of Analytical Chemistry, Adana, Turkey \\ 3inönü University Faculty of Pharmacy, Department of Analytical Chemistry, Malatya, Turkey \\ ${ }^{4}$ Anadolu University Yunus Emre Vocational School, Department of Pharmacy, Program in Pharmacy Services, Eskișehir, Turkey \\ 5Hacettepe University Faculty of Pharmacy, Department of Pharmaceutical Technology, Ankara, Turkey
}

\begin{abstract}
Objectives: The aim of this study was to determine the acid dissociation constant ( $\mathrm{pKa}$ ) of piroxicam using high performance liquid chromatography (HPLC) and ultraviolet-visible (UV-Vis) spectrophotometry, and to determine the partition coefficient (Log P), distribution coefficient (Log D), and "Log kw" values of piroxicam using HPLC.

Materials and Methods: The HPLC studies were performed on a reversed-phase ACE C18 $(150 \times 4.6 \mathrm{~mm} \mathrm{ID,} 5 \mu \mathrm{m})$ column at a flow rate of $1.0 \mathrm{~mL}$ $\mathrm{min}^{-1}$. The detector was set to $360 \mathrm{~nm}$. Log $\mathrm{D}$ at different $\mathrm{pH}$ values (3.0-6.5) was examined with a phosphate buffer (20 mM) and acetonitrile (30:70 $\mathrm{v} / \mathrm{v}$ ) mixture as the mobile phase. For pKa determination, HPLC studies were performed with a mixture of phosphate buffer (20 mM) and methanol within the $\mathrm{pH}$ range of 3.50-6.00. Log kw measurements were performed with phosphate buffer (20 mM) and MeOH (from 20:80 v/v to 10:90 v/v) mixtures within the $\mathrm{pH}$ range of 3.50-6.00. UV-Vis spectrophotometric pKa measurements were performed at $285 \mathrm{~nm}$ wavelength.

Results: The pKa value of piroxicam was found to be 5.3 by HPLC and 5.7 by UV-Vis spectrophotometry. Log P of piroxicam was determined as 1.58 in our experimental conditions. Log D values were 1.57, 1.57, 1.44, 1.13, and 0.46 for pH values of 3.17, 3.79, 4.44, 5.42, and 6.56, respectively.

Conclusion: In the literature, different $\log P(3.1,2.2$, and 0.6 ) and $\mathrm{pKa}$ (6.3 and 4.8) values were reported for piroxicam. The Log $\mathrm{P}(1.58)$ and pKa (5.3 and 5.7) values obtained for piroxicam in our study were within the range of the literature values. All these results indicate that different experimental approaches used for the determination of physicochemical properties could provide different values. Although UV spectrophotometry is easy to apply, HPLC is a unique technique for simultaneous determination of pKa, Log D, and Log P values of compounds.
\end{abstract}

Key words: Piroxicam, physicochemical properties, pKa, Log P, Log D, Log kw

öz

Amaç: Bu çalıșmanın amacı, yüksek performanslı sıvı kromatografisi (HPLC) ve ultraviyole-görünür bölge (UV-GB) spektrofotometresi kullanılarak piroksikamın asit ayrıșma sabitinin (pKa) bulunması; HPLC kullanılarak partisyon katsayısı (Log P), dağılım katsayısı (Log D) ve "Log kw” değerlerininin belirlenmesidir.

Gereç ve Yöntemler: HPLC çalışmaları, 1,0 mL min-1 akış hızında ters faz kromatografisinde ACE C18 (150x4,6 mm ID, $5 \mu \mathrm{m})$ kolon kullanılarak gerçekleştirildi. Detektör 360 nm'ye ayarlandı. Farklı pH değerlerinde (3,0-6,5) Log D değeri, hareketli faz olarak fosfat tamponu (20 mM): asetonitril (30:70 h/h) karışımı ile incelendi. pKa'nın belirlenmesi için HPLC çalışmaları, 3,50 ve 6,00 pH aralığında fosfat tamponu (20 mM): metanol karışımı ile gerçekleştirildi. Log kw ölçümleri, pH 3,50 ila 6,00 arasında bir pH aralığında fosfat tamponu (20 mM): MeOH (20:80 h/h ile 10:90 h/h) karışımları ile yapıldı. UV-GB spektrofotometrik pKa ölçümleri $285 \mathrm{~nm}$ dalga boyunda gerçekleștirildi.

Bulgular: Piroksikamın pKa değeri sırasıyla HPLC ile 5,3 ve UV-GB spektrofotometresi ile 5,7 olarak bulundu. Deney şartlarımızda piroksikamın Log P değeri 1,58 olarak bulundu. Log D değerleri, sırasıyla 3,17, 3,79, 4,44, 5,42 ve 6,56 pH değerleri için 1,57, 1,57, 1,44, 1,13 ve 0,46 olarak bulundu.

Sonuç: Literatürde, piroksikam için farklı Log P $(3,1,2,2$ ve 0,6$)$ ve pKa $(6,3$ ve 4,8) değerleri bildirilmiştir. Çalışmamızda piroksikam için elde edilen Log P $(1,58)$ ve pKa $(5,3$ ve 5,7) değerleri literatür değerleri arasındaydı. Tüm bu sonuçlar, fizikokimyasal özelliklerin belirlenmesinde kullanılan farklı deneysel yaklaşımların farklı değerler verebileceğini göstermektedir. UV spektrofotometresinin uygulanması kolay olsa da, HPLC, bileşiklerin pKa, Log $D$ ve Log P değerlerinin eşzamanlı olarak belirlenmesi için eşsiz tekniklerden biridir.

Anahtar kelimeler: Piroksikam, fizikokimyasal özellikler, pKa, Log P, Log D, Log kw

*Correspondence: E-mail: celebier@hacettepe.edu.tr, Phone: +90 (312) 3051499 ORCID-ID: orcid.org/0000-0001-7712-5512

Received: 25.02.2019, Accepted: 05.09.2019

-Turk J Pharm Sci, Published by Galenos Publishing House. 


\section{INTRODUCTION}

Dissolution from the dosage form is one of the factors limiting the absorption of drugs from the gastrointestinal (GI) tract. According to the Noyes-Whitney dissolution model, ${ }^{1}$ the in vivo dissolution rate is influenced by drug diffusivity, drug solubility in Gl contents, the wetted surface area of solid by biological fluids, and Gl hydrodynamics. ${ }^{2}$

Non-steroidal anti-inflammatory drugs (NSAIDs) are chronically used as anti-inflammatory, analgesic, and antipyretic agents ${ }^{3}$ to reduce pain, decrease stiffness, and improve function in patients suffering from all forms of arthritis. They are also used for the acute treatment of pain associated with headaches, dysmenorrhea, and postoperative pain. ${ }^{4}$ Recent studies have focused on the usage of NSAIDs for cancer treatment and prevention. ${ }^{5}$ Pharmacologic treatment of cancer pain using NSAIDs has also been investigated for a long time, ${ }^{6}$ although their use is limited due to their side effects. ${ }^{7}$ The relationship between some Gl tract diseases and NSAIDs usage is also discussed. ${ }^{8}$ Drug-drug interactions related with the usage of NSAIDs are still an issue to be investigated. ${ }^{9}$ Because of all these aspects, the physicochemical properties of drugs are one of the key points in understanding their behavior inside the body. Therefore, to understand the drug's behavior in the Gl tract, it is important to know the lipophilicity and pKa of drugs. ${ }^{10}$

Piroxicam is a NSAID of the oxicam class and is used to alleviate the symptoms of painful and inflammatory conditions such as arthritis. $^{3}$ They are also used for the treatment of headaches, dysmenorrhea, and postoperative pain. ${ }^{4}$

In the literature, it is easy to find various studies on the determination of the pKa values of pharmaceuticals using high performance liquid chromatography (HPLC), ${ }^{11-14}$ ultraviolet (UV) spectrophotometry, ${ }^{15-17}$ capillary electrophoresis, ${ }^{18,19}$ and potentiometric titrations. ${ }^{20-22}$ Identical analytical techniques have also been applied over a long period for calculation of partition coefficient ( $\log P$ ) and distribution coefficient ( Log D) values. ${ }^{23-30}$ For piroxicam, the reported Log $P$ values differ from 0.6 to 3.6 and the reported pKa values differ from 4.76 to 6.30 according to DrugBank. Variable results in such basic physicochemical parameters motivated us to investigate these parameters in our conditions. In the present study, a simple experimental procedure based on HPLC and UV-visible (Vis) spectrophotometry was applied for the determination of the physicochemical properties ( $\mathrm{pKa}, \log \mathrm{P}$, and $\log \mathrm{D}$ ) of piroxicam (Figure 1). A comparison of HPLC and UV-Vis spectrophotometry used for the determination of $\mathrm{pKa}$ values was also carried out. A chromatographic approach based on Log kw is suggested in the literature ${ }^{31,32}$ to determine the lipophilicity of drugs. This technique is relatively new compared to the classical shake-flask method, ${ }^{33}$ and, to the best of our knowledge, there is no report available in the literature to correlate the shake-flask method and Log kw measurements with each other. Therefore, this is the only study to compare the Log $P$ and Log kw measurements for an active pharmaceutical ingredient.

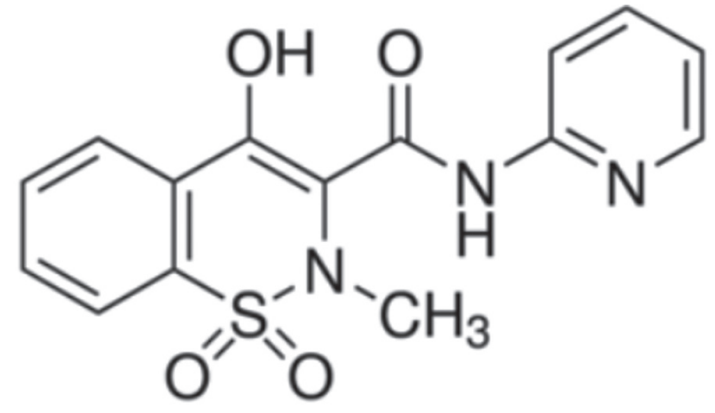

Figure 1. Chemical structure of piroxicam

\section{MATERIALS AND METHODS}

\section{Chemicals}

Piroxicam was supplied by Sigma Aldrich (St. Louis, MO, USA). Sodium dihydrogen phosphate $\left(\mathrm{NaHPO}_{4} \cdot 2 \mathrm{H}_{2} \mathrm{O}\right)$ and $\mathrm{NaOH}$ were purchased from Merck (Darmstadt, Germany). Disodium hydrogen phosphate $\left(\mathrm{Na}_{2} \mathrm{HPO}_{4} \cdot 2 \mathrm{H}_{2} \mathrm{O}\right)$, potassium chloride $(\mathrm{KCl})$, acetonitrile $(\mathrm{ACN})$, methanol $(\mathrm{MeOH})$, and 1-octanol were obtained from Sigma Aldrich. Water was obtained from the Milli-Q water system (Barnstead, USA) and used for the preparation of all standard solutions and buffers.

\section{Instrumentation}

The HPLC system used was equipped with a gradient pump (Spectra System P2000), a degasser (Spectra System SCM 1000), a manual injector with a 20- $\mu \mathrm{L}$ injection loop (Rheodyne), and a detector (Spectra System UV2000, Thermo Separation Products, USA). The detector was adjusted to 360 $\mathrm{nm}$, and retention times were determined automatically by an online computer equipped with ChromQuest software. The separations were performed using a reversed-phase (RP) ACE C18 $(125 \times 4.6 \mathrm{~mm}$ ID, $5 \mu \mathrm{m})$ HPLC column (Aberdeen,

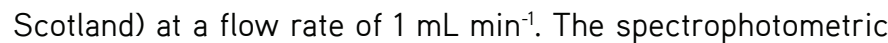
measurements were carried out using a Varian Cary 50 UV-Vis wavelength spectrophotometer with a xenon lamp (200-800 $\mathrm{nm}$ ). The UV spectra of reference and sample solutions were determined in $1-\mathrm{cm}$ quartz cells at wavelengths from 200 to $800 \mathrm{~nm}$.

\section{Solutions}

Standard stock solution of piroxicam (1000 $\mathrm{g} \mathrm{mL}^{-1}$ in MeOH) Piroxicam standard stock solution was prepared by dissolving piroxicam (50 mg) in $\mathrm{MeOH}$ in a volumetric flask $(50 \mathrm{~mL}$ ).

Phosphate buffer (20 mM) with potassium chloride (100 $m M$ ) solution (between $\mathrm{pH} 3.00$ and 7.50) for UV-Vis spectrophotometric $p K a$ determination

A phosphate buffer $(20.0 \mathrm{mM})$ and $100 \mathrm{mM} \mathrm{KCl}$ mixture were prepared by dissolving $3.56 \mathrm{~g}$ of sodium dihydrogen phosphate $\left(\mathrm{NaH}_{2} \mathrm{PO}_{4} \cdot 2 \mathrm{H}_{2} \mathrm{O}\right)$ and $7.45 \mathrm{~g}$ of $\mathrm{KCl}$ in about $800 \mathrm{~mL}$ of water and then making up the volume to $1000 \mathrm{~mL}$ with water. The $\mathrm{pH}$ of the solutions was adjusted with $1 \mathrm{M} \mathrm{NaOH}$ and $0.1 \mathrm{M} \mathrm{KCl}$ mixture solution. 
Phosphate buffer $(20 \mathrm{mM}) \mathrm{MeOH}(50: 50 \mathrm{v} / \mathrm{v})$ solutions (between $\mathrm{pH} 3.50$ and 6.00) for HPLC pKa determination

Phosphate buffer (20.0 mM) was prepared by dissolving 3.12 $\mathrm{g}$ of sodium dihydrogen phosphate $\left(\mathrm{NaH}_{2} \mathrm{PO}_{4} \cdot 2 \mathrm{H}_{2} \mathrm{O}\right)$ in about $800 \mathrm{~mL}$ of water and then making up the volume to $1000 \mathrm{~mL}$ with water. The mobile phase was prepared as $500 \mathrm{~mL}$ of a mixture of phosphate buffer $/ \mathrm{MeOH}(50: 50 \mathrm{v} / \mathrm{v})$ and the $\mathrm{pH}$ was adjusted with o-phosphoric acid/MeOH (50:50 v/v) or $20 \mathrm{mM}$ disodium hydrogen phosphate $\left(\mathrm{Na}_{2} \mathrm{HPO}_{4}\right) / \mathrm{MeOH}(50: 50 \mathrm{v} / \mathrm{v})$ mixtures for different $\mathrm{pH}$ values in the range of 3.64-5.94.

Phosphate buffer $(20 \mathrm{mM}$ ) solutions (between $\mathrm{pH} 3.00$ and 6.60) for Log $D$ determination

Phosphate buffer (20.0 mM) was prepared by dissolving 3.56 $\mathrm{g}$ of disodium hydrogen phosphate $\left(\mathrm{Na}_{2} \mathrm{HPO}_{4} \cdot 2 \mathrm{H}_{2} \mathrm{O}\right)$ in about $800 \mathrm{~mL}$ of water and then making up the volume to $1000 \mathrm{~mL}$ with water, and adjusting the $\mathrm{pH}$ with o-phosphoric acid to different $\mathrm{pH}$ values in the range of 3.17-6.56.

Phosphate buffer ( $20 \mathrm{mM}, \mathrm{pH}$ 3.0):ACN (30:70 v/v) solutions as the HPLC mobile phase for $\log D$ determination

Phosphate buffer (20.0 mM) was prepared by dissolving 3.56 $\mathrm{g}$ of disodium hydrogen phosphate $\left(\mathrm{Na}_{2} \mathrm{HPO}_{4} \cdot 2 \mathrm{H}_{2} \mathrm{O}\right)$ in about $800 \mathrm{~mL}$ of water, adjusting the $\mathrm{pH}$ with o-phosphoric acid to 3.0, and then making up the volume to $1000 \mathrm{~mL}$ with water. The mobile phases were prepared as $500 \mathrm{~mL}$ of a mixture of phosphate buffer (20 mM, pH 3.0) and ACN (30:70 v/v).

Phosphate buffer (20 mM):MeOH (from 20:80 v/v to 10:90 $v / v$ ) solutions for Log $k w$ determination (between $p H 3.00$ and 6.00)

Phosphate buffer (20.0 mM) was prepared by dissolving 3.56 $\mathrm{g}$ of disodium hydrogen phosphate $\left(\mathrm{Na}_{2} \mathrm{HPO}_{4} \cdot 2 \mathrm{H}_{2} \mathrm{O}\right)$ in about $800 \mathrm{~mL}$ of water and then making up the volume to $1000 \mathrm{~mL}$ with water. The mobile phases were prepared as $500 \mathrm{~mL}$ of a mixture of phosphate buffer $(20 \mathrm{mM}) / \mathrm{MeOH}$ in the range of 20:80-10:90, v/v. The $\mathrm{pH}$ of the mobile phases was adjusted with o-phosphoric acid/MeOH (20:80-10:90, v/v) or $20 \mathrm{mM}$ disodium hydrogen phosphate $\left(\mathrm{Na}_{2} \mathrm{HPO}_{4}\right) / \mathrm{MeOH}(20: 80-10: 90$, $\mathrm{v} / \mathrm{v})$ mixtures for different $\mathrm{pH}$ values (3.00 and 6.00) and different mobile phase compositions (phosphate buffer (20 $\mathrm{mM}) / \mathrm{MeOH}$ in the range of 20:80-10:90, v/v).

\section{Procedures}

\section{UV-Vis spectrophotometric $p K a$ determination}

The standard stock solution of piroxicam was diluted to $20.0 \mu \mathrm{g}$ $\mathrm{mL}^{-1}$ by using phosphate buffer ( $\left.20 \mathrm{mM}\right): \mathrm{KCl}(100 \mathrm{mM})$ solutions for UV-Vis spectrophotometric pKa determination $(\mathrm{pH}$ 3.097.48). The spectra were recorded at wavelengths from 200 to $400 \mathrm{~nm}$. The shifts in absorption were considered. A sigmoidal curve was constructed between $\mathrm{pH}$ of the solutions and absorption at $285 \mathrm{~nm}$. The pKa of piroxicam was determined according to the sigmoidal relationship given by Microsoft Excel between $\mathrm{pH} 3.09$ and 7.48 .

\section{HPLC pKa determination}

The standard stock solution of piroxicam was diluted to $5.0 \mu \mathrm{g}$ $\mathrm{mL}^{-1}$ with phosphate buffer $(20 \mathrm{mM}): \mathrm{MeOH}(50: 50 \mathrm{v} / \mathrm{v})$ solutions for HPLC pKa determination ( $\mathrm{pH}$ 3.64-5.94). These solutions were injected into the HPLC system with the mobile phases in which they were dissolved. A sigmoidal curve was constructed between the $\mathrm{pH}$ of the mobile phases and the capacity factor ( $\left.\mathrm{k}^{\prime}\right)$ of piroxicam. The pKa of piroxicam was determined according to the sigmoidal relationship between pH 3.64 and 5.94.

\section{Log $D$ determination}

The experimental system was a modified shake-flask method to meet the requirements of the OECD guideline for the testing of chemicals. ${ }^{33}$ For this purpose, the standard stock solution of piroxicam was diluted to $250 \mu \mathrm{g} \mathrm{mL}^{-1}$ with $\mathrm{MeOH}$. Then 50.0 $\mu \mathrm{L}$ of this solution was added to aqueous biphasic systems containing phosphate buffer (20 mM) solutions for Log D determination $(\mathrm{pH}$ 3.17-6.56) and 1-octanol (50:50 v/v, 950 $\mu \mathrm{L}$ ). After extraction at ambient temperature, the amount of piroxicam remaining in the buffer was determined by HPLC. A phosphate buffer ( $20 \mathrm{mM}, \mathrm{pH} 3.0)$ :ACN (30:70 v/v) mixture was used as a mobile phase and the buffer phase of the extracted sample was diluted 5 -fold with the mobile phase before injection into the HPLC system. Peak areas were compared with $5.0 \mu \mathrm{g}$ $\mathrm{mL}^{-1}$ piroxicam solution to determine the piroxicam amount that partitioned into the octanol phase.

\section{Log $P$ determination}

The lipophilicity of a compound can be expressed by its Log $P$, which is the concentration ratio of a nonionized compound in a mixture of two immiscible phases (aqueous and organic phases) at equilibrium. For measurement of the Log $P$ value of a weakly basic drug, piroxicam, the equation given below is used for different $\mathrm{pH}$ values. The average of the obtained results was calculated to find the Log $P$ value.

$\log \mathrm{D}=\log \mathrm{P}-\log \left(1+10^{\mathrm{pKa}-\mathrm{pH}}\right) \quad$ Equation 1

\section{Log kw determination}

For determination of Log kw values, piroxicam was diluted to $5.0 \mu \mathrm{g} \mathrm{mL}^{-1}$ using phosphate buffer (20 mM):MeOH (from 20:80 $\mathrm{v} / \mathrm{v}$ to $10: 90 \mathrm{v} / \mathrm{v}$ ) solutions ( $\mathrm{pH} 3.00$ and 6.00 ). The relationship between Log $\mathrm{k}^{\prime}$ and $\mathrm{MeOH}$ concentration in the mobile phase is described by Log $k^{\prime}=\log k w-S \phi{ }^{31,34}$ In this equation, $k w$ is the $k^{\prime}$ value for a compound when the aqueous phase is used as the eluent, $S$ is the slope of the regression line, and $\phi$ is the volume percentage of $\mathrm{MeOH}$ in the mobile phase. If $\phi$ is zero (no $\mathrm{MeOH}$ in the mobile phase), the mobile phase is composed of only the phosphate buffer and the Log $\mathrm{k}^{\prime}$ will be equal to the Log kw

\section{Measurements on sigmoidal curves}

The data measured from the sigmoidal curve for $\mathrm{pKa}$ determination were found using two different approaches. The first one was to print the whole graph on A4 paper and find the pKa values by drawing tangents. The second one was to use the derivative of the actual graph. 


\section{Statistical analysis}

Measurements were performed as three replicates and the results were statistically evaluated to obtain standard deviation and standard error for the calculations. The mean values were used to present the data.

\section{RESULTS AND DISCUSSION}

In the present study, we focused on the pKa, Log P, and Log $D$ values of piroxicam because the reported values are very different from each other. The Log kw values of piroxicam were also evaluated and the values were compared with the Log D values. Based on the statistical evaluation, mean values were used to present the results.

\section{UV-Vis spectrophotometric $p K a$ determination}

Absorption of organic compounds including most of the drugs is based on transitions of $n$ or $n$ electrons to the $\pi^{*}$ excited state. The absorption peaks for these transitions fall in the 200-700 nm range, which is the experimentally convenient region of the spectrum. The transitions referred to require an unsaturated group in the molecule to provide $\pi$ electrons. The solvent in which the absorbing species are dissolved may have serious effects on the spectrum. ${ }^{35}$ In the present study, the spectra of piroxicam in the phosphate buffers having identical ionic strengths (adjusted with $0.1 \mathrm{M} \mathrm{KCl}$ ) but at different $\mathrm{pH}$ values from 3.09 to 7.48 were recorded. The values between 3.09 and 7.48 were used to construct the sigmoidal curve at $285 \mathrm{~nm}$ wavelength. The characteristic of the absorption spectrum for piroxicam was changed by changing the $\mathrm{pH}$ of the buffered aqueous media (Figure 2). The changes in the absorbance values are usually followed by overlaid plots of recorded spectra, and the greatest change occurs when the acidity of the aqueous solution is equal to the pKa of the studied compound. The sigmoidal curve was constructed and the pKa value of piroxicam was estimated as 5.7 (Figure 3 ).

\section{HPLC pKa determination}

The capacity factor of a drug in a RP-HPLC system is related to its lipophilicity. ${ }^{36,37}$ Since weak acidic drugs like piroxicam are ionized at basic $\mathrm{pH}$, they tend to be eluted rapidly from a

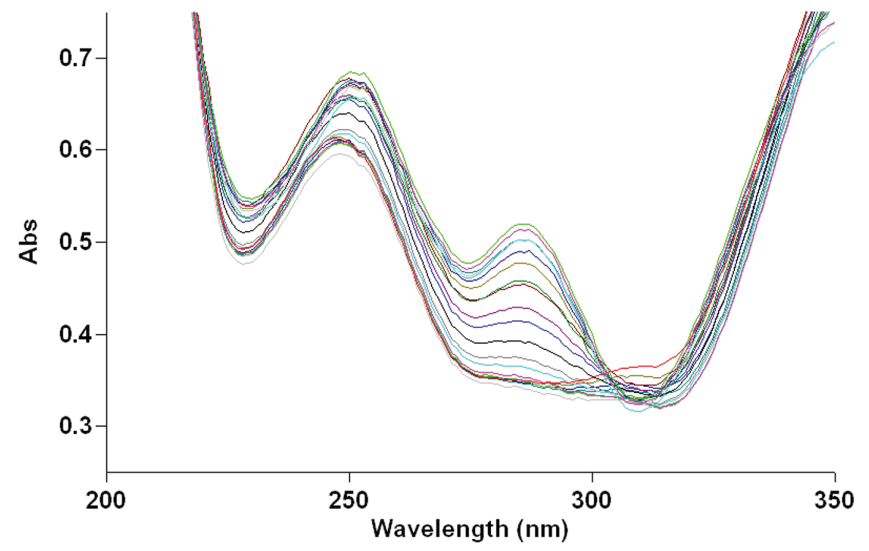

Figure 2. Representative overlaid spectra $(200-400 \mathrm{~nm})$ of piroxicam under optimum conditions at various $\mathrm{pH}$ values $(\mathrm{pH} 3.09-7.48)$ lipophilic $\mathrm{C}_{18}$ stationary phase with basic mobile phases. The situation is the opposite for acidic mobile phases. Our results are in good agreement with this statement. Piroxicam was eluted at $7.44 \mathrm{~min}$ at acidic $\mathrm{pH}(\mathrm{pH} 3.64)$ and eluted at 4.34

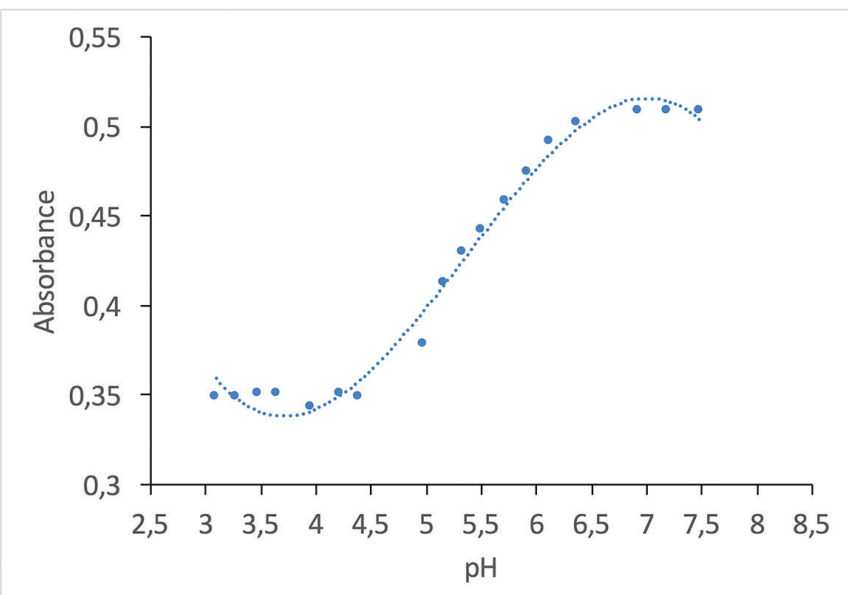

Figure 3. The plot of the absorbance values of piroxicam at $285 \mathrm{~nm}$ obtained as a function of $\mathrm{pH}$ (3.09-7.48)

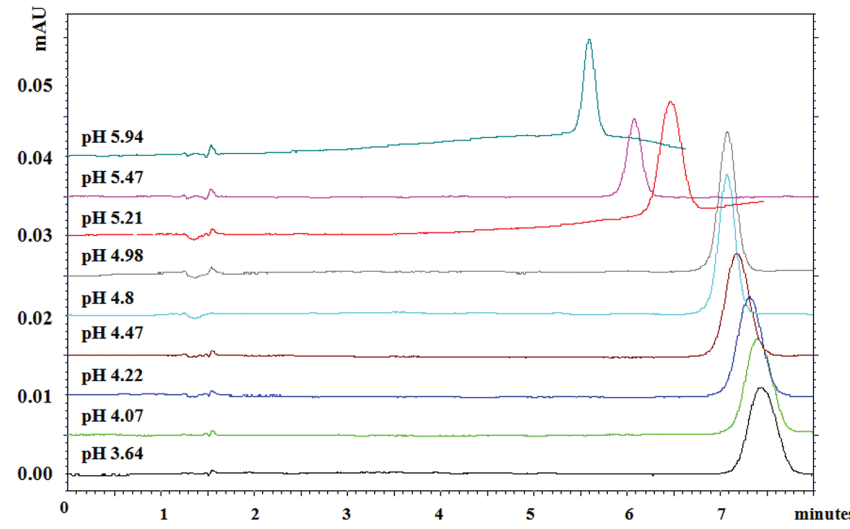

Figure 4. Representative overlaid chromatograms of piroxicam taken under optimum conditions at various $\mathrm{pH}$ (3.64-5.94) values. $\mathrm{pH}$ values are given on the top of each chromatogram peak

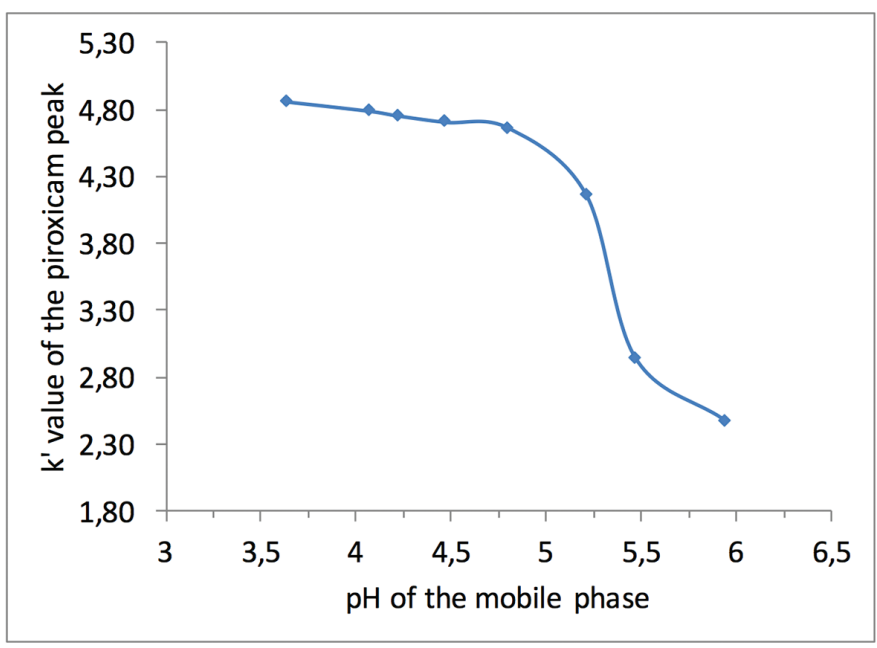

Figure 5. Sigmoidal relationship between $\mathrm{pH}$ (3.64-6.22) and $\mathrm{k}^{\prime}$ of the piroxicam peak 
min at relatively basic $\mathrm{pH}(\mathrm{pH}$ 5.94) values (Figure 4). When the $\mathrm{pH}$ value of the mobile phase was plotted against $\mathrm{k}$ ' values, a sigmoidal relationship was obtained between $\mathrm{pH}$ and capacity factor (Figure 5). The pKa value of piroxicam was calculated as 5.3 from this relationship.

\section{$\log D$ and $\log P$ determination}

In drug discovery and development, the lipophilicity of a compound is usually expressed by its partition between water and 1-octanol. The concentration of a nonionized compound in the organic and aqueous phases refers to Log P. The Log $P$ of any ionizable solution can be measured in the aqueous phase in which the $\mathrm{pH}$ is adjusted to the nonionized form. The concentration ratio of nonionized solute in the solvents is calculated according to the Log $\mathrm{P}$ value, which is a measure of lipophilicity and is not $\mathrm{pH}$ dependent (Equation 2).

$\log P_{\text {oct/wat }}=\log \left(\frac{\text { [solute }_{\text {octanol }}}{\text { [solute](nonionized water }}\right)$ Equation 2

As described above, piroxicam is a weak base, and it is partially ionized when dissolved in water. $\log D$ is the ratio of the sum of the concentrations of all forms of the compound (ionized plus nonionized) in each phase and is $\mathrm{pH}$ dependent. The distribution coefficient is defined as a function of the ratio of the total concentration of the solute species in each phase (Equation 3). ${ }^{38}$

$\log D_{\text {(oct/wat) }}=\log \left(\frac{\text { [solute }_{\text {octanol }}}{\text { [solute](nonionized water }+[\text { solute] neutral water }}\right)$

Equation 3

For a non-ionized drug, $\log \mathrm{P}$ is equal to $\log \mathrm{D}$ at any $\mathrm{pH}$ value, but the effective lipophilicity at any specific $\mathrm{pH}$ value is directly related to its $\mathrm{pKa}$ value for any ionized drug. In our experimental conditions, Log D of piroxicam was investigated at $\mathrm{pH} 3.17,3.79$, 4.44, 5.42, and 6.56. Table 1 summarizes the Log $D$ values of piroxicam at the investigated $\mathrm{pH}$ values. The Log $\mathrm{P}$ values given in Table 1 were calculated according to Equation 1, in which the pKa of piroxicam was accepted as 5.7 and 5.3 based on the UV spectrophotometric and HPLC measurements, respectively.

Since piroxicam is an acidic drug, it is ionized at basic $\mathrm{pH}$ values and tends to be dissolved in aqueous phases. As expected, the solubility of piroxicam in the aqueous phase (phosphate buffer) was increased about 13-fold by the changes in $\mathrm{pH}$ from 6.56 to 3.17. This situation was in harmony with the capacity factor of piroxicam on HPLC for different mobile phase $\mathrm{pH}$ values. Although $\log \mathrm{D}$ values differ with $\mathrm{pH}$ values, calculated Log $P$ values should be identical according to the theory. When the mean and standard error of $\log P$ values were calculated it was found that Log $P$ was $1.58 \pm 0.04$ if pKa was taken as 5.3 and $1.46 \pm 0.05$ if pKa was taken as 5.7. This shows us that the pKa value of 5.3 determined by HPLC provides a lower standard error for the calculated Log $P$ values. Therefore, the Log $P$ value for piroxicam was accepted as 1.58 in our experimental conditions.

\section{Log kw determination}

Since the retention time of an analyte in RP-HPLC is directly related to its lipophilicity, this relationship can be used to show how the lipophilicity of an analyte will be affected by $\mathrm{pH}$ changes. In our study, initially we calculated the Log k' values for all mobile phase compositions (80:20, 85:15, 90:10 $\mathrm{MeOH}$ :phosphate buffer $(20 \mathrm{mM}) ;(\mathrm{v} / \mathrm{v})$ for $\mathrm{pH}$ values below (3.0) and above (6.0) the calculated pKa (5.3). The Log k' values were calculated for the mobile phase not containing any organic phase $(0 \% \mathrm{MeOH})$. Figure 5 shows an example of this application for $\mathrm{pH}$ 6.0. When there was no $\mathrm{MeOH}$ in the mobile phase, the $\mathrm{kw}^{\prime}$ values were calculated for $\mathrm{pH} 3.0$ and 6.0 and found to be 37.5 and 7247.7 , respectively.

\section{CONCLUSION}

In this study, spectrophotometric and chromatographic analytical approaches were examined to determine the physicochemical properties of piroxicam. Since piroxicam is a well-known compound, the results were easily compared with those in DrugBank (https://www.drugbank.ca/drugs/ DB00554). According to our experimental results, the pKa value was found to be 5.7 and 5.3 for the spectrophotometric and HPLC experiments, respectively. The value found by UVVis spectrophotometry is close to the experimental value of 6.3 given in DrugBank. However, the predicted value of 4.76 given in DrugBank is close to the one calculated by the results of HPLC analysis. The experimental Log P value in DrugBank for piroxicam is 3.06, where the predicted values are 0.6 and 2.2. Our experiments show that piroxicam's Log $P$ value is 1.58 . This value is between the predicted and experimental values

Table 1. Experimental Log $D$ and calculated Log $P$ values of piroxicam

$\mathrm{pH} \quad \log \mathrm{L} \quad \log \mathrm{D}$

$\log P \quad \log P$

(pKa is accepted as 5.3) (pKa is accepted as 5.7)

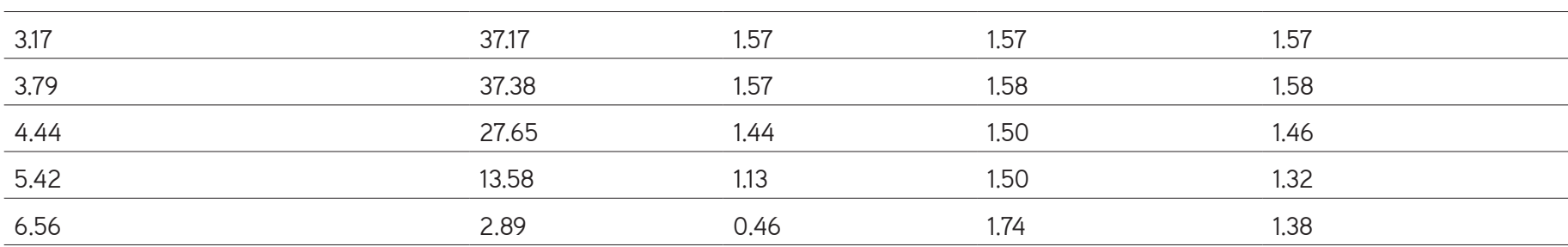

Log D: Distribution coefficient, Log P: Partition coefficient, pKa: Dissociation constant 
reported in DrugBank. The differences for pKa and Log $\mathrm{P}$ between the experimental and predicted values in DrugBank indicate that the experimental data found in the present study are novel for piroxicam. Based on all these results, we can conclude that the use of different experimental approaches for the determination of physicochemical properties can clearly provide different values for drugs.

Conflicts of interest: No conflict of interest was declared by the authors. The authors alone are responsible for the content and writing of the paper.

\section{REFERENCES}

1. Costa P, Lobo JMS. Modeling and comparison of dissolution profiles. Eur J Pharm Sci. 2001;13:123-133.

2. Hörter D, Dressman J. Influence of physicochemical properties on dissolution of drugs in the gastrointestinal tract. Adv Drug Deliv Rev. 2001;46:75-87.

3. Crofford LJ. Use of NSAIDs in treating patients with arthritis. Arthritis Res Ther. 2013;15(Suppl 3):S2.

4. Simon LS. Nonsteroidal anti-inflammatory drugs and their risk: a story still in development. Arthritis Res Ther. 2013;15(Suppl 3):S1.

5. Cha YI, DuBois RN. NSAIDs and cancer prevention: targets downstream of COX-2. Annu Rev Med. 2007;58:239-252.

6. Portenoy RK, Lesage P. Management of cancer pain. The Lancet. 1999;353:1695-1700.

7. Carr DB, Goudas LC, Balk EM, Bloch R, loannidis J, Lau J. Evidence report on the treatment of pain in cancer patients. JNCI Monographs. 2004;32:23-31.

8. Rainsford KD, Velo GP. Side-effects of anti-inflammatory drugs: part two studies in major organ systems: Springer Science \& Business Media; 2012.

9. Franz CC, Egger S, Born C, Bravo AER, Krähenbühl S. Potential drugdrug interactions and adverse drug reactions in patients with liver cirrhosis. Eur J Clin Pharmacol. 2012;68:179-188.

10. Dressman J, Vertzoni M, Goumas K, Reppas C. Estimating drug solubility in the gastrointestinal tract. Eur J Clin Pharmacol. 2007;59:591-602.

11. Uhrova M, Miksik I, Deyl Z, Bellini S. Determination of dissociation constants by separation methods (HPLC and CE). Theoretical background and guidelines for application. Process Contr Qual. 1997;10:151-167.

12. Oumada FZ, Rafols C, Roses M, Bosch E. Chromatographic determination of aqueous dissociation constants of some water-insoluble nonsteroidal antiinflammatory drugs. J Pharm Sci. 2002;91:991-999.

13. Demiralay EC, Koc D, Daldal YD, Çakır C. Determination of chromatographic and spectrophotometric dissociation constants of some beta lactam antibiotics. J Pharmaceut Biomed. 2012;71:139-143.

14. Canbay HS, Demiralay EC, Alsancak G, Ozkan SA. Chromatographic Determination of pK(a) Values of Some Water-Insoluble Arylpropionic Acids and Arylacetic Acids in Acetonitrile plus Water Media. J Chem Eng Data. 2011;56:2071-2076.

15. Santos E, Rosillo I, Delcastillo B, Avendano C. Determination of Pka Values for Hydantoins by Spectrophotometry. J Chem Res-S. 1982:131.

16. Rosenberg LS, Simons J, Schulman SG. Determination of Pka Values of N-Heterocyclic Bases by Fluorescence Spectrophotometry. Talanta. 1979;26:867-871.
17. Pereira AV, Garabeli AA, Schunemann GD, Borck PC. Determination of Dissociation Constant (K-a) of Captopril and Nimesulide - Analytical Chemistry Experiments for Undergraduate Pharmacy. Quim Nova. 2011;34:1656-1660.

18. Fu XF, Liu Y, Li W, Bai Y, Liao YP, Liu HW. Determination of dissociation constants of aristolochic acid I and II by capillary electrophoresis with carboxymethyl chitosan-coated capillary. Talanta. 2011;85:813-815.

19. Ehala S, Misek J, Stara IG, Stary I, Kasicka V. Determination of acid-base dissociation constants of azahelicenes by capillary zone electrophoresis. J Sep Sci. 2008;31:2686-2893.

20. Schurman H, Thun $H$, Verbeek F. Potentiometric Determination of Dissociation Constants of Itaconic Acid. J Electroanal Chem. 1970;26:299-305.

21. Qiang ZM, Adams C. Potentiometric determination of acid dissociation constants (pK(a)) for human and veterinary antibiotics. Water Res. 2004;38:2874-2890.

22. Roda G, Dallanoce C, Grazioso G, Liberti V, De Amici M. Determination of Acid Dissociation Constants of Compounds Active at Neuronal Nicotinic Acetylcholine Receptors by Means of Electrophoretic and Potentiometric Techniques. Anal Sci. 2010;26:51-54.

23. Mirrlees MS, Moulton SJ, Murphy CT, Taylor PJ. Direct measurement of octanol-water partition coefficients by high-pressure liquid chromatography. J Med Chem. 1976;19:615-619.

24. Haky JE, Young AM. Evaluation of a simple HPLC correlation method for the estimation of the octanol-water partition coefficients of organic compounds. J Liq Chromatogr. 1984;7:675-689.

25. Kaliszan R, Haber P, Baczek T, Siluk D. Gradient HPLC in the determination of drug lipophilicity and acidity. Pure Appl Chem. 2001;73:1465-1475.

26. Yamana T, Tsuji A, Miyamoto E, Kubo O. Novel method for determination of partition coefficients of penicillins and cephalosporins by high[ pressure liquid chromatography. J Pharm Sci. 1977;66:747-749.

27. Wiczling P, Kawczak P, Nasal A, Kaliszan R. Simultaneous determination of $p \mathrm{~K}$ a and lipophilicity by gradient RP HPLC. Anal Chem. 2006;78:239249.

28. Singh S, Sharda N, Mahajan L. Spectrophotometric determination of nimesulide through ion-pair complex formation with hexadecyltrimethylammonium bromide. Int J Pharm. 1999;176:261-264.

29. Völgyi G, Ruiz R, Box K, Comer J, Bosch E, Takács-Novák K. Potentiometric and spectrophotometric pKa determination of waterinsoluble compounds: validation study in a new cosolvent system. Anal Chim Acta. 2007;583:418-428.

30. Cleveland Jr J, Benko M, Gluck S, Walbroehl Y. Automated $\mathrm{p}\langle\mathrm{i}\rangle \mathrm{K}\langle/$ $i\rangle\langle$ sub $\rangle\langle\langle/$ sub $\rangle$ determination at low solute concentrations by capillary electrophoresis. J Chromatogr A. 1993;652:301-308.

31. Hong H, Wang L, Zou G. Retention in RP-HPLC: Lipophilicity determination of substituted biphenyls by reversed-phase high performance liquid chromatography. J Liq Chromatogr Relat Technol. 1997;20:3029-3037.

32. Markuszewski MJ, Wiczling P, Kaliszan R. High-throughput evaluation of lipophilicity and acidity by new gradient HPLC methods. Comb Chem High Throughput Screen. 2004;7:281-289.

33. Kocak E, Celebier M, Altinoz S. Validation of spectrophotometric method to quantify varenicline content in tablets. Asian J Chem. 2013;25:18451848.

34. Braumann T. Determination of hydrophobic parameters by reversedphase liquid chromatography: theory, experimental techniques, and 
application in studies on quantitative structure-activity relationships. J Chromatogr A. 1986;373:191-225.

35. Celik H, Buyukaga M, Celebier M, Turkoz Acar E, Baymak MS, GokhanKelekci N, Palaska E, Erdoğan H. Determination of pKa values of some benzoxazoline derivatives and the structure-activity relationship. J Chem Eng Data. 2013;58:1589-1596.

36. Demiralay EC, Alsancak G, Ozkan SA. Determination of pKa values of nonsteroidal antiinflammatory drug-oxicams by RP-HPLC and their analysis in pharmaceutical dosage forms. J Sep Sci. 2009;32:29282936.

37. Wiczling P, Kawczak P, Nasal A, Kaliszan R. Simultaneous determination of pKa and lipophilicity by gradient RP HPLC. Anal Chem. 2006;78:239249.

38. Royal Society of Chemistry, Learn Chemistry, Partition and distribution coefficients Available from: http://www.rsc.org/learn-chemistry/ resource/ 